\section{Michigan Technological \begin{tabular}{ll}
\hline $\mathbf{1} 8 \mathbf{8} 5$ & University \\
\hline
\end{tabular}}

Michigan Technological University Digital Commons @ Michigan Tech

\title{
Estimating particle sizes, concentrations, and total mass of ash in volcanic clouds using weather radar
}

\author{
David M. Harris \\ The University of Alberta \\ William I. Rose \\ Michigan Technological University
}

Follow this and additional works at: https://digitalcommons.mtu.edu/geo-fp

Part of the Geology Commons, Mining Engineering Commons, and the Other Engineering Commons

\section{Recommended Citation}

Harris, D. M., \& Rose, W. I. (1983). Estimating particle sizes, concentrations, and total mass of ash in volcanic clouds using weather radar. AGU Publications, 88(C15), 10969-10983. http://dx.doi.org/10.1029/ JC088iC15p10969

Retrieved from: https://digitalcommons.mtu.edu/geo-fp/136

Follow this and additional works at: https://digitalcommons.mtu.edu/geo-fp

Part of the Geology Commons, Mining Engineering Commons, and the Other Engineering Commons 
ESTIMATING PARTICLE SIZES, CONCENTRATIONS, AND TOTAL MASS OF ASH IN VOLCANIC CLOUDS USING WEATHER RADAR

David M. Harris 1

Department of Geology, The University of Alberta

William I. Rose, Jr.

Department of Geology and Geological Engineering, Michigan Technological University

\begin{abstract}
Observations of the March 19, 1982 ash eruption of Mount St. Helens, made by the National Weather Service (NWS, Portland, Oregon) on $5-\mathrm{cm}$ radar, were used to estimate the volume of the ash cloud $\left(2000+500 \mathrm{~km}^{3}\right)$, the concentration of ash $\left(0.2-0.6 \mathrm{~g} \mathrm{~m}^{=3}\right)$, and the total mass of ash erupted $\left(3-10 \times 10^{11} \mathrm{~g}\right)$. The position of the cloud was also tracked by radar. Particle sizes in the ash cloud were estimated from set$t$ ling velocities suggested by decreases in maximum ash cloud height with time as it moved away from the volcano. The March 19, 1982 ash blanket was sampled and mapped. Ash fallout times and accumulation rates were reconstructed from ground observations. Grain size distributions for various samples were used to obtain particle concentration $\left(0.2 \mathrm{~g} \mathrm{~m}^{-3}\right)$, total ashfall mass $\left(1-3 \times 10^{11} \mathrm{~g}\right)$, and radar reflectivity factor $\left(4-5 \mathrm{~mm}^{6} \mathrm{~m}^{-3}\right)$ for the ash cloud. Our preferred estimate for total ashfall mass $\left(4 \times 10^{11} \mathrm{~g}\right)$ is that obtained from the product of the ash cloud volume determined by radar $\left(2000+500 \mathrm{~km}^{3}\right)$ and the particle concentration inferred from ashfal 1 data $\left(0.2 \mathrm{~g} \mathrm{~m}^{-3}\right)$. Previously published ashfall data for the May 18, 1980 Mount St. Helens eruption has been studied using our ashfall inversion technique to estimate 6-hour mean particle concentration $\left(3 \mathrm{~g} \mathrm{~m}^{-3}\right)$, the size distribution, total ashfall mass $\left(5 \times 10^{14} \mathrm{~g}\right)$, and radar reflectivity factors $\left(7-60 \mathrm{~mm}^{6} \mathrm{~m}^{-3}\right.$ ) for the ash cloud. A somewhat higher value $\left(9 \mathrm{~g} \mathrm{~m}^{-3}\right)$ for particle concentration was estimated from radar observations [Harris et al., 1981] for an ash cloud formed during the peak eruption rate at Mount St. Helens. The two independent estimates are consistent, given the many uncertainties of the problem. The reflectivity factors for very dense ash clouds (3-9 $\mathrm{g} \mathrm{m}^{-3}$ ) are several orders of magnitude smaller than for severe weather considered routinely detectable by airborne weather radar and dangerous for aviation. Because volcanic ash clouds with particle concentrations of at least $0.2 \mathrm{~g} \mathrm{~m}^{-3}$ are produced in extremely small eruptions (in terms of total ashfall mass) of duration less than 1 minute, volcanic ash clouds must be considered an extremely serious hazard to In-flight aircraft, regardless of eruption magnitude. These factors should be considered in hazard evaluations for known volcanoes
\end{abstract}

\footnotetext{
$\mathbf{1}_{\text {Now with IRT Corporation. }}$
}

Copyright 1983 by the American Geophysical Union.

Paper number $3 \mathrm{Cl} 393$. 0148-0227/83/003C-1393\$05.00 located near air routes, Radar observations and calculations can provide scientists monitoring eruptive activity with significant information for estimating duration of eruption, particle concentrations in ash clouds, total mass of solid material erupted, magma eruption rate, potential ashfall mass, ashfall locations and accumulation rates, and duration and amounts of ashfa11. Detailed analysis of ashfall data and NWS radar observations of ash clouds from Mount St. Helens demonstrate that weather radar can yield such timely information during and following volcanic eruptions.

\section{Introduction}

Known hazards might be mitigated and public safety would be enhanced if the locations, times, and amounts of volcanic ash in the atmosphere could be predicted during an eruption. The theory and applications of weather radar for remote sensing of volcanic ash clouds are described by Harris et a1. [1981]. Some of the eruptions of Augustine volcano (Alaska) in 1976 were observed on weather radar; the most detailed account is probably that given by Kienle and Shaw [1979]. Use of weather radar for est1mating ashfall amounts requires an independent technique for evaluating the accuracy of particle concentrations, their sizes and distributions, and the total amounts of volcanic ash estimated for radar-detected ash clouds. Mathematical inversion of volcanic ashfal1 data provides a suitable technique. The purpose of this paper is to compare the particle concentrations, their sizes, and the potential ashfall mass inferred from the radar observations and calculations using the radar equation for distributed targets [Probert-Jones, 1962] with the same quantities inferred independently from volcanic ashfal 1 observations.

One of the classical problems for radar meteorology is to determine from reflectivity data the areal rainfall or the precipitation content of storms. With carefully calibrated radars, many experiments have shown that these quantities can be estimated to within perhaps a factor of two of the correct values. The dielectric constant is accurately known; the form of the drop size distribution can sometimes be safely assumed. In this study the particles to be sensed are of variable composition, shape, and size distributions and are being sensed by an uncalibrated radar system. Even so, we believe our results are encouraging, interesting, and useful. All figures based on radar measurements in this paper are reported in the text to one significant figure, although in our 
tables, so that our calculations can be checked, we have used two significant figures.

The first part of this paper concerns radar observations of the ash cloud from the March 19, 1982 Mount St. Helens eruption and physical quantities inferred from use of the radar equation. The second part summarizes field and laboratory studies of ashfall from this eruption. The third part considers the problem of estimating typical particle concentrations in ash clouds from the much larger eruption of Mount St. Helens on May 18, 1980, In view of measured ashfa11 amounts [Sarna-Wojcicki et al., 1981], transport mechanisms [Carey and Sigurdsson, 1982; Danielsen, 1982; Danielsen et al., 1982], particle aggregation [Rose and Hoffman, 1982; Sorem, 1982], and radar observations [Harris et al., 1981]. The final part is a discussion and summary of the principal results.

Radar Observations of the March 19, 1982 Eruption

This eruption of Mount St. Helens began at 1928 PST with a very small Plinian ash column. The seismicity associated with this event is high amplitude harmonic tremor that occurred in two intervals: 1928:20-1929:00 and 1929:20 1929:30; selsmicity continued at considerably lower amplitudes and may be attributed to a mudf low that originated in the crater about this time. These considerations suggest that the ash eruption was largely produced in an interval of about 40-50 seconds [S. Malone, oral communication, 1982]. Later activity included extrusion of a new lobe on the dacitic composite dome within the crater [Swanson, 1982]. A second, smaller ash eruption occurred about 0137 PST on March 20, 1982. Minor amounts of ash, compared to that erupted March 19, 1982, were erupted during episodic explosive release of gas during and following dome growth.

The ash cloud from this eruption was detected and tracked by Rob Nordberg on the U. S. National Weather Service (NWS) 5-cm radar in Portland, Oregon. Technical details for this radar system are given in Table 1. The maximum helght of the ash column was measured at $13.7 \mathrm{~km}$ above sea level (as1) and was attained by 1933 PST. The extremely brief duration of ash emission for this event did not permit measurement of the maintained eruption column height as a function of time. However, the ash cloud was tracked on radar and its approximate dimensions were measured at various later times.

The height of the ash cloud, as determined by radar, decreased with time owing to gravitational settling of ash particles. For example, the top of the ash cloud decreased in elevation from $13.7 \mathrm{~km}$ as 1 at 1933 PST to $10.7 \mathrm{~km}$ as 1 at 1950 PST, an apparent mean settling speed of $3.0 \mathrm{~km} / 17$ minutes $=300 \mathrm{~cm} / \mathrm{s}$. Three measurements from 2000-2030 PST showed a further decrease in elevation from $10.7 \mathrm{~km}$ as 1 to $7.6 \mathrm{~km}$ as 1 , an apparent mean sett1ing speed of 170 $\mathrm{cm} / \mathrm{s}$. These settling speeds and observation times will be used below to estimate the particle slzes in the ash cloud.

The total vertical extent of the approximately cylindrical ash cloud immediately after erup- tion was about $11+1 \mathrm{~km}$. The diameter of the radar-detected ash $c$ loud varied with helght and time, but the root mean square diameter of the cloud measured at three altitudes at two times was $15+1 \mathrm{~km}$. The volume of the ash cloud is estimated to be about $2000+500 \mathrm{~km}^{3}$. The ash cloud moved to the south-southeast from Mount St. Helens. The horizontal wind speed estimated from the ash cloud track, about $35-45 \mathrm{~km} \mathrm{~h}^{-1}$, is not very precisely determined.

\section{Particle Sizes in the Ash Cloud}

The sizes and concentrations of particles in an ash cloud play an important role in determining whether a given radar system will be able to detect the ash cloud at a specified range. The reflectivity factor $z$, which is a parameter of the radar target, is proportional to the sixth power of the particle dlameter and to the first power of the particle concentration in a unit volume in the target space [e.g., Atlas, 1964]. Consequently, the larger particles within an ash cloud make much greater contributions to the reflectivity factor than do smaller particles of equal abundance [see Harris et al., 1981]. Also, the terminal settling speeds of ash particles increase with their size and density and with height in the earth's atmosphere [e.g., Wilson, 1972]. Therefore the initlal fallout from the cloud should represent the coarsest fraction of the size distribution plus smaller particles that are scavenged by the larger ones [see Rose et a1., 1980, P1ate 8, p. 685], and their removal should diminish the reflectivity of the ash cloud. The observed decrease in maximum height of the ash cloud determined by radar from 1933 to 1950 PST is due to fallout of particles with estimated mean terminal settling speeds of $300 \mathrm{~cm} \mathrm{~s}^{-1}$ and the resulting decrease of the reflectivity factor below the minimum required for detection. The value $300 \mathrm{~cm} / \mathrm{s}$ is the settling speed of particles which make a sufficiently large contribution to the reflectivity of the ash cloud for their removal to result in nondetection of the residual, finer ash. Similarly, the decrease in height from

TABLE 1. Specifications of NWS Radar at Portland, Oregon

\begin{tabular}{|c|c|c|}
\hline & Specific & eations \\
\hline \multirow[t]{2}{*}{ Location } & $45^{\circ} 36^{\prime}$ & $\begin{array}{l}\text { north } \\
\text { latitude }\end{array}$ \\
\hline & $122^{\circ} 36^{\prime}$ & $\begin{array}{l}\text { west } \\
\text { longitude }\end{array}$ \\
\hline Peak transmitted power & 230 & kw \\
\hline Horizontal beam width & 1.65 & deg \\
\hline Vertical beam width & 1.65 & deg \\
\hline Pulse duration & 3 & $\mu \mathrm{s}$ \\
\hline Pulse length & .9 & $\mathrm{~km}$ \\
\hline Wavelength & 5 & $\mathrm{~cm}$ \\
\hline Sensitivity & 103 & $\mathrm{dBm}$ \\
\hline Sensitivity & $5 \times 10^{-14}$ & w \\
\hline Pulse repetition rate & 259 & $\mathrm{~Hz}$ \\
\hline Maximum range & 400 & $\mathrm{~km}$ \\
\hline
\end{tabular}

Source: Table 32 of Harris et a1. [1981], with a correction for units of pulse duration 
TABLE 2. Recommended Measurements of Eruption Clouds Using Weather Radar

\begin{tabular}{|c|c|c|c|}
\hline Measurements & Indicator & Applications & Examples \\
\hline $\begin{array}{l}\text { Height of eruption column } \\
\text { above volcano during } \\
\text { sustained eruptions }\end{array}$ & RHI & $\begin{array}{l}\text { evaluate hazards to alrcraft using air } \\
\text { space } \\
\text { estimate duration of ash emission } \\
\text { estimate magma eruption rate } \\
\text { estimate total amount of ash erupted }\end{array}$ & $\begin{array}{l}\text { Harris et al. } \\
\text { [1981, } \\
\text { Figure 190, } \\
\text { Table 33, } \\
\text { text] }\end{array}$ \\
\hline $\begin{array}{l}\text { Maximum height of ash clouds } \\
\text { at known locations downwind } \\
\text { and at known times }\end{array}$ & RHI & $\begin{array}{l}\text { estimate settling speeds of largest } \\
\text { particles within the ash clouds at } \\
\text { various times } \\
\text { estimate particle sizes from settling } \\
\text { speeds at altitude observed }\end{array}$ & $\begin{array}{l}\text { this paper } \\
\text { this paper }\end{array}$ \\
\hline $\begin{array}{l}\text { Horizontal and vertical } \\
\text { dimensions of ash cloud }\end{array}$ & PPI, RHI & $\begin{array}{l}\text { estimate volume of ash cloud } \\
\text { estimate duration of ash fall } \\
\text { from individual ash clouds }\end{array}$ & this paper \\
\hline $\begin{array}{l}\text { Locations, areal extent, } \\
\text { and horizontal velocity } \\
\text { of ash cloud at various } \\
\text { times }\end{array}$ & PPI, RHI & $\begin{array}{l}\text { forecast locations, times, and } \\
\text { duration of heaviest ashfall } \\
\text { by using future locations and } \\
\text { transit times of ash clouds }\end{array}$ & $\begin{array}{l}\text { Harris et al. } \\
\text { [1981, } \\
\text { Figure 191, } \\
\text { Table 35] }\end{array}$ \\
\hline
\end{tabular}

2000 to 2030 PST gives the settling speed $(170 \mathrm{~cm} / \mathrm{s})$ of some smaller particles that had longer retention times within the ash cloud. Weather radar can be used to estimate, in real time, the size of the falling ash particles by paying particular attention to the top of the eruption cloud as it drifts downwind. Accurate estimates depend on the assumption of no vertical air motion. This assumption may not be valid, especially near vigorous eruption columns. This is a very useful, different application of radar measurements. If the sizes of the ash particles can be constrained by radar observations, then the radar calculations can be used to estimate total ashfall mass, ashfall accumulation rates, and ashfall amounts. A list of measurements which can and should be made on volcanic ash clouds by radar systems near active volcanoes are given in Table 2, together with the applications.

The particle sizes may be inferred from their terminal settling speeds by using a relation between particle size and density, altitude, and mean fall speeds (see Figure 1, based upon fall times in Wilson's [1972] Figures 2 and 3). Terminal settling speeds of $300 \mathrm{~cm} \mathrm{~s}^{-1}$ at $12 \mathrm{~km}$ for vesicular tephra and plagioclase with an assumed bulk density of $2.5 \mathrm{~g} \mathrm{~cm}^{-3}$ suggest particles $0.25 \mathrm{~mm}$ in diameter. Similarly, terminal settling speeds of $170 \mathrm{~cm} \mathrm{~s}^{-1}$ at $9 \mathrm{~km}$ for similar tephra suggest particles $0.18 \mathrm{~mm}$ in diameter. Although ash considerably finer than $0.18 \mathrm{~mm}$ was present (see ashfall observations, below), its concentration must have been below the detection 1 imit for the radar system at this range, since some ash finer than $0.18 \mathrm{~mm}$ would have remained within the upper part of the ash cloud after depletion in the coarser fraction. Obviously, the changing vertical profiles of maximum particle sizes and threshold target reflectivities required for detection by radar provide sufficient information for placing upper or lower bounds (depending upon observations) on particle concentrations in the ash cloud. A conclusion of these observations is that the major portion of the ash cloud reflectivity responsible for its detection by NWS $5-\mathrm{cm}$ radar was that due to particles between 0.1 and $0.3 \mathrm{~mm}$ diameter. This is the same range which brackets the mean grain size of ash which fel1 10-50 km downwind and made up the largest volume component of this ash blanket. This is important because it shows that radar detected ash with particle sizes approximating that of contemporaneous fallout. Hence radar measurements may be used to estimate particle sizes in ash clouds and ashfall.

Particle Concentrations in the Ash Cloud

The minimum particle concentrations in the ash cloud were estimated by the procedure described by Harris et a1. [1981], which is outlined below. Probert-Jones's [1962] expression for the received power $P_{r}$ from a target composed of randomly distributed targets is

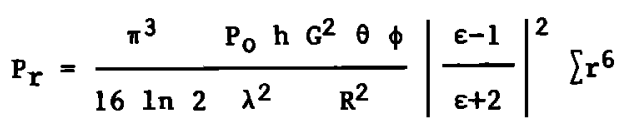

where

$P_{r}$ received power;

Po peak transmitted power;

$h$ radar pulse length in space (distance);

$G$ actual gain of antenna;

$\theta$ horizontal beam width to the $-3 \mathrm{~dB}$ level for one-way transmission;

$\phi$ vertical beam width to the $-3 \mathrm{~dB}$ level for one-way transmission;

$\varepsilon$ dielectric constant of spherical particles;

$\lambda$ wavelength;

$R$ range;

$r$ radius of spherical particles.

The sumation $\left[\mathbf{r}^{6}\right.$ is taken over a11 the particles of various sizes in a unit volume of target space. Equation 1 above is valid when the target completely fills the beam as defined by $\theta$, 

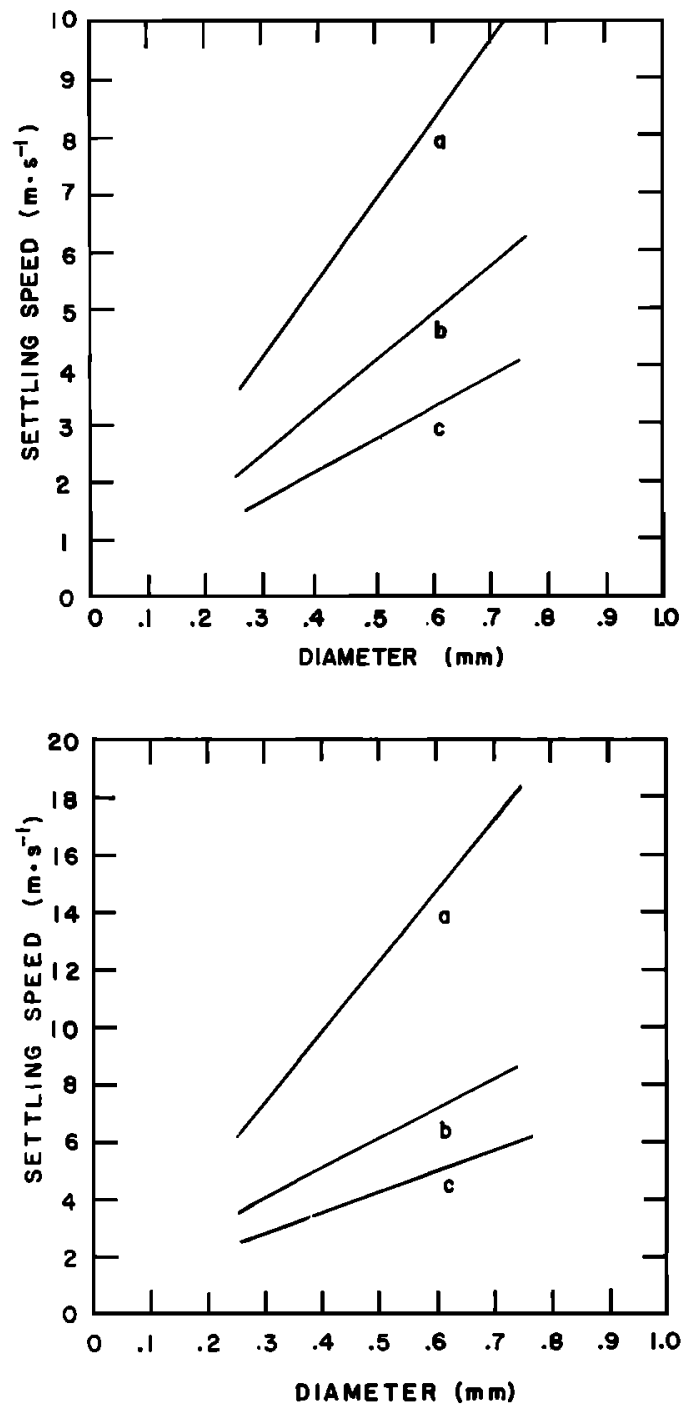

Fig. 1. (top) Mean terminal velocities for settling of spherical particles with density = $1.0 \mathrm{~g} \mathrm{~cm}^{-3}$ through three altitude intervals, (a) 30 to $20 \mathrm{~km}$; (b) 20 to $10 \mathrm{~km}$; (c) 10 to 5 $\mathrm{km}$, as functions of particle diameter. Data are from Figure 2 of Wilson [1972]. (bottom) Same as (top), except for particles with density = $2.5 \mathrm{~g} \mathrm{~cm}^{-3}$. Data are from Figure 3 of Wilson [1972].

$\phi$, and $h$ at a particular range $R$. The actual gain $G$ is the antenna gain along the beam axis relative to an isotropic radiator. The gain is related to the beam widths by

$$
G=\frac{\pi^{2} k^{2}}{\theta_{\phi}}
$$

where $k$ is a factor that corrects for the nonuniformity of 11 lumination of the antenna [Probert-Jones, 1962]; $k$ is approximately unity for antennas of circular cross section.

Equation (1) includes four variables in addition to those specific to a particular radar system. The terms $P_{O}, h, \lambda, G, \theta$, and $\phi$ are radar system parameters and are constant for a particular radar system. The term $|(\varepsilon-1) /(\varepsilon+2)|^{2}$ depends upon the dielectric constant $(\varepsilon)$ of the particles. The term $\sum \mathbf{r}^{6}$ depends upon the size distribution and number density of the particles in the target. The term $1 / R^{2}$ depends upon the distance (range) between the radar system and the target. The term for received power $P_{r}$ is a function of all of the above. Therefore, for a particular radar system, the variables in the radar equation are $\sum r^{6}, R, \varepsilon$, and $P_{r}$. A solution can be obtained if three of the variables are known.

By using the particle sizes inferred from the radar observations of the ash cloud height at various times and the threshold particle concentrations required for detection, we can place limits on the concentrations of particles within the ash cloud (see appendix for detalls). The estimated lower and upper bounds for the concentration of ash with nominal diameters larger than $0.18 \mathrm{~mm}$ are about 0.2 and $0.6 \mathrm{~g} \mathrm{~m}^{-3}$, respectively. The concentration of ash finer than $0.18 \mathrm{~mm}$ cannot be determined from the present radar observations because the number of such particles is too small to raise the $\left(\sum \mathrm{r}^{6}\right)$ term to the limit of radar detection. These initial concentrations are those required for radar detection of the ash cloud at various times and altitudes. The true concentration lies within the range given, with the actual value dependent upon the size distribution of ash.

\section{Potential Ashfall Mass}

The potential ashfall mass can be estimated from the volume of the radar detected ash cloud (about $2000 \mathrm{~km}^{3}$ ) and the inferred lower and upper bounds for the particle concentrations $\left(0.2-0.6 \mathrm{~g} \mathrm{~m}^{-3}\right)$ to be between $3 \times 10^{11} \mathrm{~g}$ and $1 \times 10^{12} \mathrm{~g}$ (300,000 to $1,000,000$ metric tons). This estimate assumes that the lower part of the ash cloud initially contained particle size distributions and concentrations similar to those of the upper half of the ash cloud which was observed on radar. This assumption seems plausible because the updraft velocities in-

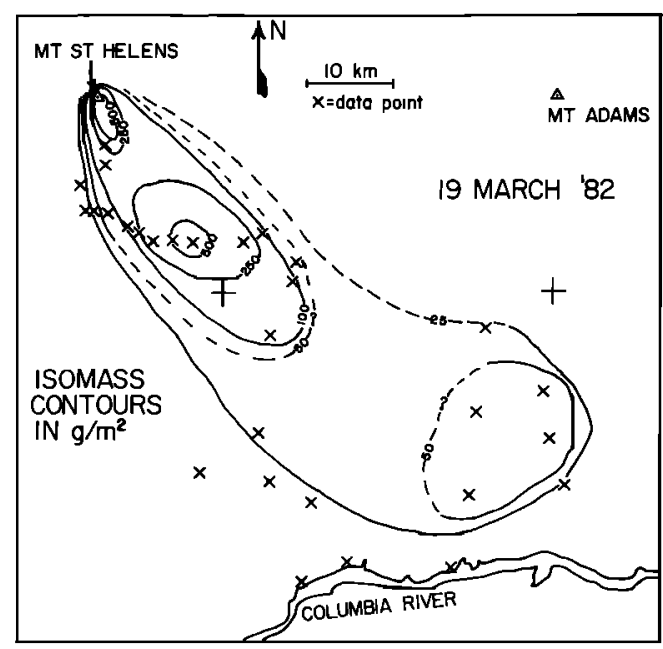

Fig. 2. Isomass map of air fall ash of the March 19-20, 1982 eruption. Contours give ashfall amounts in grams per square meter. 


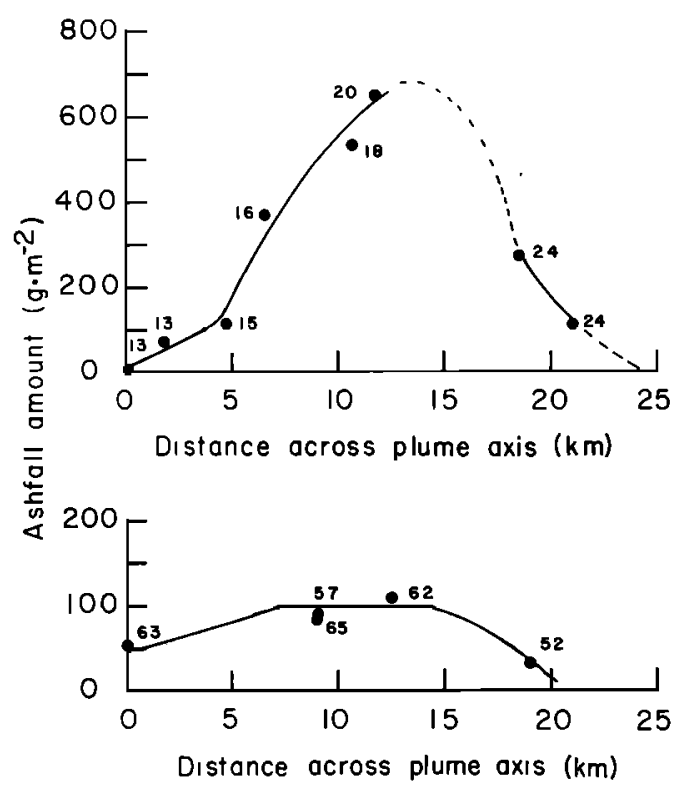

Fig. 3. Profiles of total ashfall amounts measured along two transects approximately normal to the axis of maximum ashfall. Numbers adjacent to points give distance to volcano in kilometers.

ferred for the Plinian eruption columns at Mount St. Helens on May 18 and August 7,1980 were 44 and $43 \mathrm{~m} / \mathrm{s}$, respectively [Rose et al., 1982, p. 6], and these values great 1 y exceed terminal settling speeds for particles considered here. Since the estimated potential ashfall masses are only lower and upper bounds, respectively, a better estimate would be the geometric mean of the two limits, $6 \times 10^{11} \mathrm{~g}$, with an overa 11 uncertainty equal to a factor of two. This estimate does not consider all ash finer than $0.18 \mathrm{~mm}$.

\section{Ashfall Rates}

The ashfall rate cannot be forecast exactly without more detailed knowledge of the particle size distribution than is available from the present radar data. However, order of magnitude estimates can be made. Using $0.2 \mathrm{~g} \mathrm{~m}^{-3}$ as an order of magnitude estimate for the concentration of particles with diameters near $0.25 \mathrm{~mm}$ and $190 \mathrm{~cm} / \mathrm{s}$ as their mean settling speed from 5 to $0 \mathrm{~km}$ [Wilson, 1972], one obtains an estimated ashfall rate of $1000 \mathrm{~g} \mathrm{~m}^{-2} \mathrm{hr}^{-1}$. Similarly, using $0.4 \mathrm{~g} \mathrm{~m}^{-3}$ as the order of magnitude estimate for the concentration of particles with diameters near $0.18 \mathrm{~mm}$ and $90 \mathrm{~cm} / \mathrm{s}$ as their mean settling speed from 5 to $0 \mathrm{~km}$ [Wilson, 1972], one obtains an estimated ashfall rate of $1300 \mathrm{~g} \mathrm{~m}^{-2} \mathrm{hr}^{-1}$. These values represent neither maxima nor minima, but only order of magnitude estimates.

Field Observations of the March 19, 1982 Ashfall

\section{Ashfall Amounts}

The distribution of ashfall was observed and sampled at 31 sites located 5 to $75 \mathrm{~km}$ south- southeast of Mount St. Helens (Table 3). Measured total ashfal1 amounts were contoured on a map to show lines of equal ashfall mass per unit area (Figure 2). The variations define an axis of maximum ashfali with an approximate azimuth of $125^{\circ}$ from Mount St. Helens. Total ashfall amounts decrease with distance from the axis (Figure 3). Along the axis, total ashfall amounts initially decrease with increasing distance from Mount St. Helens, there is a minimum near $10 \mathrm{~km}$, there is a second maximum near $20 \mathrm{~km}$ (Figure 2 and 4), and the amounts decrease beyond about $20 \mathrm{~km}$. Light ashfall was reported at least as far away as Hermiston, Oregon, about $230 \mathrm{~km}$ east-southeast of Mount St. Helens, which is outside the area we have studied. The width of the depositional area (i.e., normal to the axis) is about $15-20 \mathrm{~km}$ at a range up to $25 \mathrm{~km}$ and increases at greater distances (Figures 2 and 3). The total ashfal 1 mass was integrated, following the method of Rose et a1. [1983] which includes a rationale for estimating ash which fell outside of measured contours. The total ashfall mass is between about $1.0 \times 10^{11}$ and $3.0 \times 10^{11} \mathrm{~g}(100,000$ to 300,000 metric tons $)$.

\section{Particle Sizes}

The particle size distributions of some ashfall samples along the axis of maximum ashfall were determined. The median particle sizes decrease and the degree of sorting increase for ash that fell at successively greater distances from the volcano (Figures 5 and 6 ). The maximum particle size decreases with distance from the volcano such that beyond about $30 \mathrm{~km}$ and $65 \mathrm{~km}$ the particles are finer than $0.21 \mathrm{~mm}$ and $0.15 \mathrm{~mm}$, respectively.

The existence and location of the secondary maximum of total ashfall (Figure 4) is a significant feature of unknown origin. The particle size distribution and mineralogy are influenced by the initial height of the ash column, the wind velocity, the terminal settling speeds of the particles, and aggregation phenomena [e.g., Walker, 1973; Wilson, 1972; Sarna-Wojcicki et a1., 1981; Rose and Hoffman, 1982; Sorem, 1982; Carey and Sigurdsson, 1982], making the solution complex. We have graphed the partial ashfall amounts as functions of distance from the volcano (Figure 7). The partial ashfall amounts are defined here as the product of the total ashfall amount and the mass fraction of ash within the specified particle size interval. Partial ashfall amounts for the size intervals $0.21-0.35 \mathrm{~mm}, 0.35-0.50 \mathrm{~mm}$, and $0.50-0.71 \mathrm{~mm}$ show secondary maxima downwind from the volcano (Figure 7). Three size intervals smaller than $0.21 \mathrm{~mm}$ also show relative maxima downwind from the volcano, whereas four size intervals larger than $0.71 \mathrm{~mm}$ show only maxima at or near the volcano. It is significant that the secondary maxima in Figure 7 are for individual unaggregated particles and these particles are too large for their origin as tephra clusters described by Sorem [1982]. We suggest that such secondary maxima should be typical of fine grained ash falls and are not necessarily dependent on aggregation, contrary to Carey and Sigurdsson's [1982] suggestion. 
TABLE 3. Ashfall Measurements

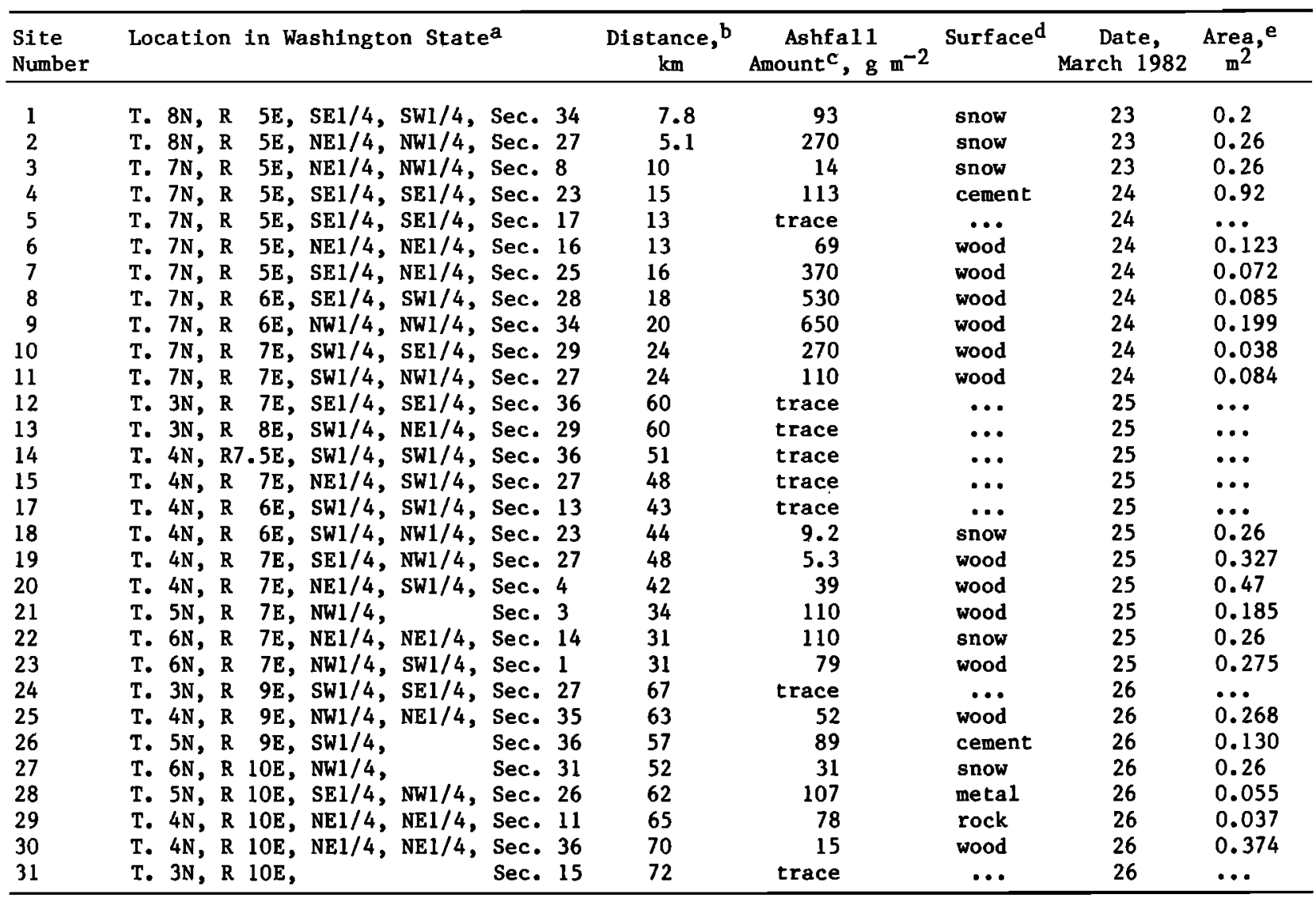

aAll sites except 30 are located on the Mount St. Helens and Vicinity 1:100,000 Sheet (March 1981, U.S. Geological Survey) or the Gifford Pinchot National Forest 1:126,720 Sheet (1976, rev. 1979; U.S. Forest Service).

bDistances are approximate and have uncertainties of about $+0.5 \mathrm{~km}$.

cAshfall amounts were calculated as the quotient of the dry mass of ash and the collection area.

dAshfall samples were obtained on horizontal surfaces of unshaded snow, metal, concrete, wood stumps of recently cut Douglas fir trees in clear cut areas, and wooden picnic tables located in clearings within the forest.

Measured surface area

Using Ground Based Ashfall Data to Estimate Particle Concentrations in Antecedent Ash Clouds

Although observations of rainfall by radar are routine and there are many techniques for estimating rainfall amounts, ashfall has two chief advantages over rainfall for purposes of estimating the size distributions and concentrations of particles in their superjacent clouds:

1. Except for aggregates of fine ash [e.g., Sorem, 1982], the ashfall amounts and the size distribution of ashfall particles are preserved for periods ranging from weeks to millions of years after deposition.

2. The whole-eruption particle size distribution is established by explosive fragmentation [Murrow et al., 1980] rather than by reversible processes such as condensation, evaporation, coalescence, and breakup. Because ash clouds are a major hazard to aircraft, however, in situ sampling of ash clouds by aircraft is not possible except during light ashfall [e.g., Hobbs et a1., 1977; Rose et a1., 1980]. Therefore we used ground-based ashfall data to obtain Information on superjacent ash clouds.

Since the instantaneous ashfall rate in grams per square meter per hour at any specified altitude is the sum-product of the local particle concentrations and their terminal settling speeds, it follows that the mean particle concentrations in grams per cublc meter for each particle size interval can be determined from the mean ashfall accumulation rates and the terminal settling speeds appropriate for each particle size interval. Use of the technique requires the following additional information: (1) the maximum altitude of the ash cloud and the time that it was attained, (2) the approximate onset time of ashfall at each site under consideration, (3) the duration of ashfall accumulation, and (4) the settling times for various pyroclasts with initial altitudes given in point 1 .

The ashfall collected at site 8, located (Table 3) $18 \mathrm{~km}$ southeast of Mount St. Helens along the northeast shore of Swift Lake, was selected for determination of particle concen- 


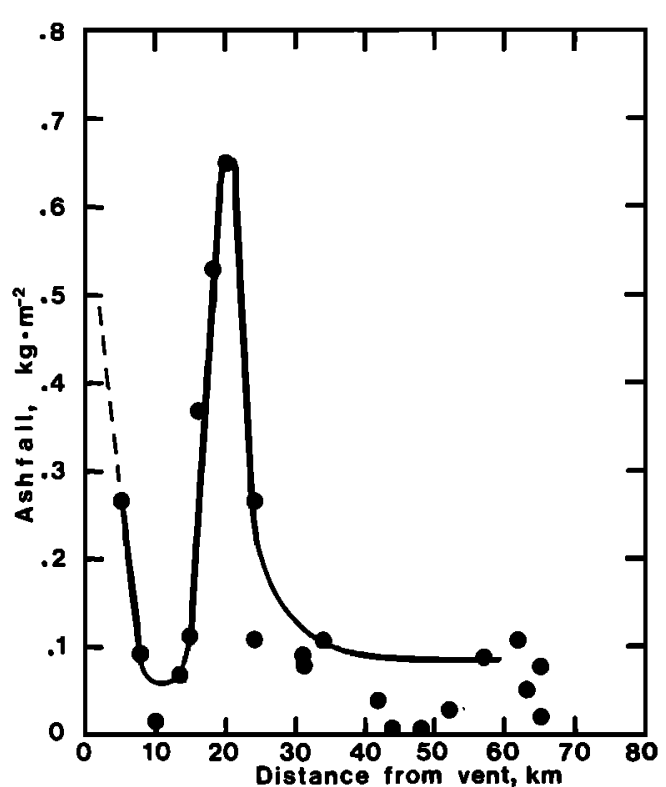

F1g. 4. Total ashfall amount as a function of distance from Mount St. Helens for the March 19-20, 1982 eruption. Points represent measured values.

trations in the ash cloud because it contains particles with diameters ranging from less than $0.15 \mathrm{~mm}$ to more than $1.0 \mathrm{~mm}$ and includes the size range of most interest, namely, that inferred from the radar observations. Also, the approximate onset time of ashfall and its duration, together with other important observations were obtained by interviewing residents of a nearby home; these people traveled in two cars over U. S. Forest Service Route 90 along the north shore of Swift lake during the half hour immediately following the eruption and arrived at a house $2 \mathrm{~km}$ east of site 8 about 1945 and 2000 PST, respectively, on March 19, 1982. The following facts were established from the interview: The observers reported seeing lightning in the vicinity of Mount St. Helens at about 1930 PST. No ashfall had occurred at Swift Camp (site 9, Table 3) or along the road from Yale to Swift Camp until after 1945 PST.

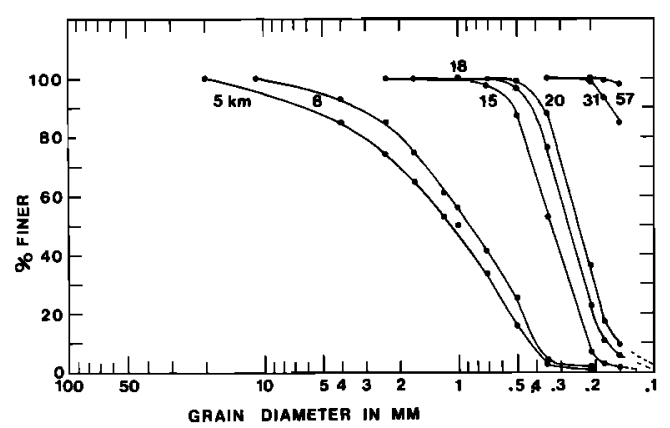

Fig. 5. Cumulative weight percent curves showing size distribution of March 19, 1982 air-fall ash at increasing distances from Mount St. Helens. The ashfall samples (Table 3, numbers $1,2,4,8,9,22,26$, and 29) were collected on or near the axis of maximum ashfall. Numbers give distance from the volcano in kilometers.

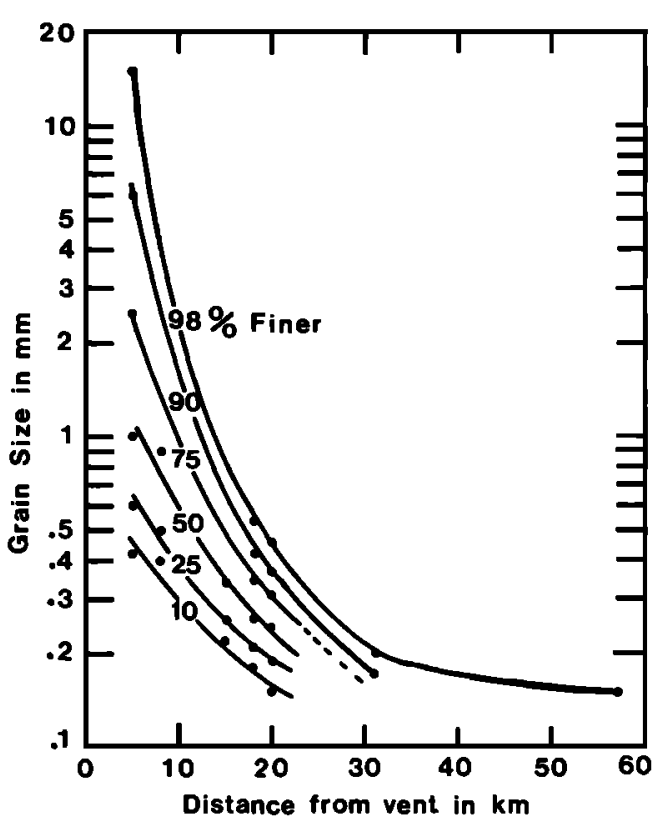

Fig. 6. Grain size characteristics of March 19, 1982 air fall ash as functions of distance from Mount St. Helens.

The driver of the second car reported the occurrence of "hail" (actually coarse tephra) between the Swift Dam Overlook and the junction between U. S. Forest Service Route 90 and the road to Marble Mountain at about 1945 PST and later observed fallout of "snow" (actual1y, sand-sized volcanic ash). From 2010 to 2015, ashfall at Swift Camp was light but continued for about two and one half hours at decreasing rates. By

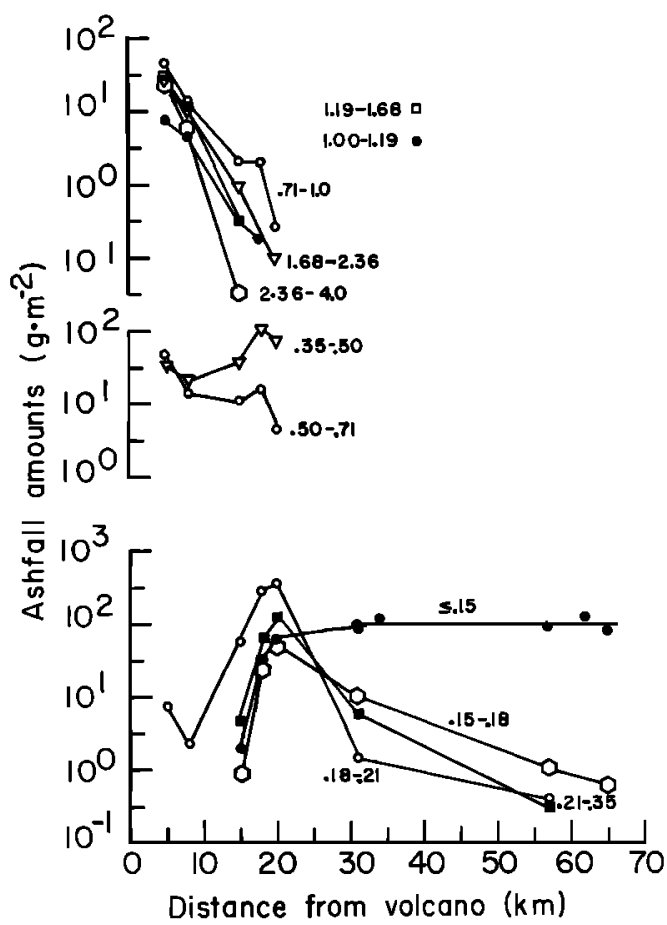

Fig. 7. Partial ashfall amounts in grams per square meter as functions of distance from the volcano for the March 19-20, 1982 eruption. 
2300 the ashfall rate was very light, and by 2330 only an occasional "flake" could be seen at Swift Camp. The best estimate for the beginning of ashfall at both sites 8 and 9 is 2010 PST, and this has an estimated uncertainty of 5 minutes.

The ashfall at site 8 was sleved and weighed to determine the particle size distribution and the partial ashfall amounts (Table 4). Then the average mass per particle was determined by weighing aliquots of 300-700 representative particles from each of five size intervals in the range $0.18-1.00 \mathrm{~mm}$ and 13 particles in the size range $1.00-2.36 \mathrm{~mm}$ (Table 5). For purposes of estimating approximate terminal settling speeds, we have calculated nominal diameters using densities of $1.0 \mathrm{~g} \mathrm{~cm}^{-3}$ and $2.5 \mathrm{~g} \mathrm{~cm}^{-3}$ for particles larger and smaller, respectively, than $0.50 \mathrm{~mm}$ because these calculated nominal diameters are consistent with the size limits for the-sieves. Maximum fallout times were estimated for these pyroclasts by using an initial height of $13.6 \mathrm{~km}$ as 1 and a final height of 0.3 $\mathrm{km}$ asl (Table 4) from calculations based upon the graphs of Wilson [1972]. The duration of fallout and hence the estimated accumilation time for each particle size interval was obtained as the difference between the respective maximum fallout time and the time elapsed (about $40 \mathrm{~min}$ ) between the eruption (1930 PST) and the onset of ashfall (about 2010 PST) at the observation site. The partial ashfall rates in grams per square meter per hour are the quotients of the partial ashfall amounts and their estimated accumulation times. Since the partial ashfall rates are the products of the concentration of particles within the specifled size intervals and their respective terminal settling speeds, the concentrations of various-sized particles within the ash cloud base can be determined using the data available (Table 4). The terminal settling speeds at ground level were assumed equal to the mean speeds for the interval $5 \mathrm{~km}$ to $0 \mathrm{~km}$, using the tabulated nominal diameters and densities and the graphs in Wilson [1972]. Do the Inferred concentrations reflect those of the ash cloud?

The inferred concentrations within each size interval at this site reflect those of the ash cloud only if the following conditions are met:

1. Prior fallout has not significantly depleted the coarse fraction for individual particle size intervals,

2. The density range of ashfall particle types within the size interval adequately represents that of the ash cloud [see Rose et al., 1980, 1983),

3. The total accumulation times are approximately correct in view of the delayed onset of ashfall expected for most sites owing to the initial helght of the ash cloud base above the earth's surface,

4. The removal of fine ash due to scavenging by larger particles or formation of tephra clusters [Sorem 1982] are adequately considered. Particles larger than $0.50 \mathrm{~mm}$ and smaller than $0.21 \mathrm{~mm}$ diameter are poorly represented in the ash sample from site 8 located $18 \mathrm{~km}$ from Mount St. Helens (Figure 7). Inferred concentrations for particles larger than $0.50 \mathrm{~mm}$ are suspect because condition 1 is not met (Figure
7). Partial ashfall amounts for particles sma1ler than $0.21 \mathrm{~mm}$ increase downwind from site 8 (Figure 7) and suggest that conditions 3 and 4 are not met at this site. The partial ashfall amounts should be near a maximum where cond1tions 1 and 2 are satisfied. Accordingly, we argue that for particles in the size ranges $0.21-0.35 \mathrm{~mm}$ and $0.35-0.50 \mathrm{~mm}$ the four cond $\mathrm{i}-$ tions are adequately satisfied at site 8 and that for these size intervals, the concentrations in the ash cloud were 0.049 and $0.025 \mathrm{~g} \mathrm{~m}^{-3}$, respective1y.

Ashfall data from other sites were used in similar manner to infer the particle concentrations in the ash cloud (Table 5). The estimate for the whole ash cloud is based upon use of maximum partial ashfall amounts (Figure 7) from five sites located $5-57 \mathrm{~km}$ from Mount Saint Helens. Owing to the location of site 2 on the flank of Mount St. Helens, maximum fallout times of 20-42 minutes for particles larger than $0.50 \mathrm{~mm}$, and the similar transit time for the ash cloud (at least $25 \mathrm{~min}$ ), we assumed that the accumulation times were approximately equal to the maximum fallout times for these particles. Data for sites 8 and 9 , located $2 \mathrm{~km}$ apart, were combined to yield estimates for particle concentrations in the size range $0.50-0.18 \mathrm{~mm}$. The apparent settling speed $\left(90 \mathrm{~cm} \mathrm{~s}^{-1}\right)$ for $0.15-$ $0.18 \mathrm{~mm}$ ash at site 9 was calculated by assuming that the factor of 50 increase in partial ashfall amounts over the interval 15-20 km (Figure 7) reflects the first ash of this size to reach the ground $(0.325 \mathrm{~km}$ asl) at 2010 PST from the Intial base of the ash cloud $(2.55 \mathrm{~km}$ asl) at 1933 PST. Similarly, the settling speed of $30 \mathrm{~cm} \mathrm{~s}^{-1}$ for ash finer than $0.15 \mathrm{~mm} 1 \mathrm{~s}$ based upon the time delay between eruption and observed fallout of aggregates of fine ash from the October 16, 1980 eruption of Mount St. Helens (D. M. Harris, unpublished data, 1980). Calculated terminal settling speeds for particles less than $0.18 \mathrm{~mm}$ differ from these empirtcal values owing to the combined effects of particle aggregation and mean vertical winds (see discussion by Wilson [1972]) that may exceed typical settling velocities for these particle sizes. The total concentration calculated for the March 19, 1982 ash cloud is $0.19 \mathrm{~g} \mathrm{~m}^{-3}$, and one third of this total amount is finer than $0.18 \mathrm{~mm}$. Finally, using the particle concentration inferred from the ashfali data and the volume of the ash cloud detected by radar, the mass erupted is estimated to be about $4 \times 10^{11} \mathrm{~g}$.

\section{Inferred Reflectivity Factors}

The ashfall data for the March 19, 1982 eruption permit an estimate of the reflectivity factor that is independent of radar observations (Table 5). The reflectivity factors per unit mass of ash were calculated from the nominal diameters and the mean particle masses for each size interval. These values were weighted according to the concentration of ash in each size interval and then summed. The maximum reflectivity factor may have been as high as $300 \mathrm{~mm}^{6} \mathrm{~m}^{-3}$, but would have decreased within 10-20 minutes to less than $10 \mathrm{~mm}^{6} \mathrm{~m}^{-3}$ owing to fallout of particles larger than $1.2 \mathrm{~mm}$; the maximum value is extremely sensitive to the con- 


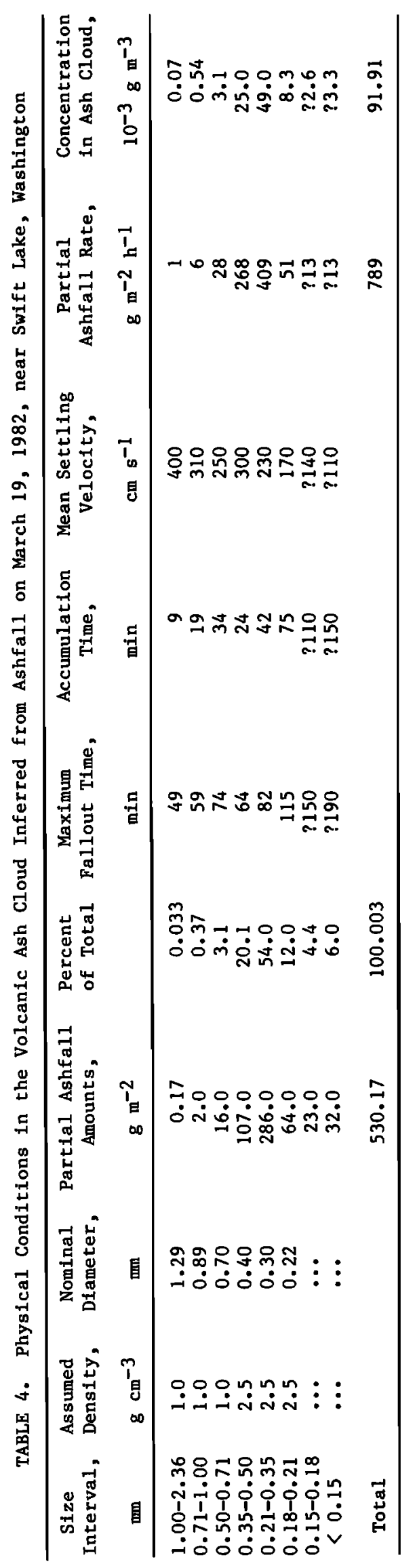

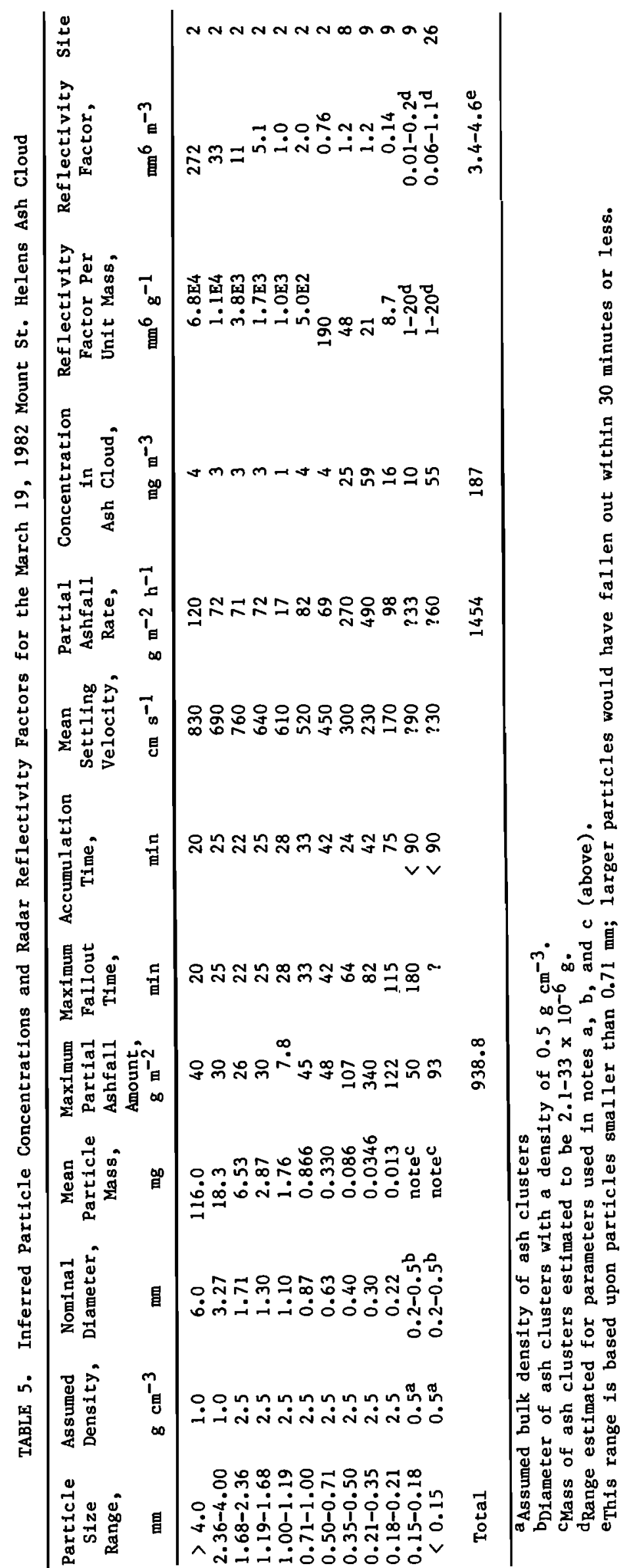


centration of particles coarser than about $1.2 \mathrm{~mm}$. The calculated reflectivity factors for the ash cloud, based upon particles smaller than $1.2 \mathrm{~mm}$, are in the range $6-8 \mathrm{~mm}^{6} \mathrm{~mm}^{-3}$, but would have decreased to $1.2-2.2 \mathrm{~mm}^{6} \mathrm{~m}^{-3}$ for regions depleted in ash coarser than $0.21 \mathrm{~mm}$.

\section{Physical Properties of the May 18, 1980 Mount St. Helens Ash Cloud}

Volcanic ash from the May 18, 1980 eruption of Mount St. Helens was detected and tracked on the Portland NWS 5-cm radar and on two Federal Aviation Administration (FAA) 23-cm radar units located in Seattle and near Spokane, Washington [Harris et al., 1981]. Calculations using the Probert-Jones [1962] radar equation and radar specifications were performed to estimate, in retrospect, the particle concentrations and potential ashfall mass in the first ash cloud [Harris et al., 1981]. On the basis of terminal settling velocities and ashfall observations, Rose and Hof fman [1982] inferred that aggregation of fine ash (e.g., $0.025 \mathrm{~mm}$ diameter) into composite particles with higher terminal settling velocities was required to explain their occurrence within the ash deposit in eastern Washington. The possible enhancement of radar reflectivities by particle aggregation was recognized by Harris et a1. [1981]. In view of unresolved questions concerning accuracy of our radar estimates of particle concentrations and ashfall mass [Lipman and Mullineaux, 1981, p. 322], new data on ashfall from this eruption [Sarna-Wojcicki et a1., 1981; Rose and Hoffman, 1982; Sorem, 1982; Carey and Sigurdsson, 1982], and the new methods for inversion of ashfall data (this paper), a reappraisal seems appropriate.

The basic ashfall data and calculations required for estimating particle concentrations, potential ashfall mass, and reflectivity factors for the ash cloud on May 18, 1980 are listed in Table 6. Partial ashfall masses for the various size intervals were calculated from representat1ve data of Sarna-Wojcicki et a1. [1981, Figures 338,342$]$. Al though the eruption lasted about 9 hours, the magma eruption rate [Harris et a1., 1981] and resulting accumulation rates of ashfal1 at proximal [Waitt et al., 1981] and distal [Critchfield, 1982, Figure 4] sites varled with time. Therefore, for purposes of estimating particle concentrations in the ash clouds responsible for high accumulation rates, we estimated that most of the ash accumulated in about 6 hours (see ashfall accumulation record for Yakima, Washington in Figure 4 of

Critchfield [1982]). The partial ashfall rates were calculated as described earlier in this paper. The settling speeds for tephra clusters comprised of ash finer than $0.14 \mathrm{~mm}$ were taken to be $0.35 \mathrm{~m} \mathrm{~s}^{-1}$ [Carey and Sigurdsson, 1982], and this value implicitly represents the difference between the terminal settling velocities of the tephra clusters in still air and the mean vertical wind speed [see Wilson, 1972]. The 6-hour mean concentrations summed for various particle size intervals (Table 6) decreased from more than $3 \mathrm{~g} \mathrm{~m}^{-3}$, at $57 \mathrm{~km}$ from the volcano, to lower values, at greater distances, as the sizes of the largest particles within the ash cloud

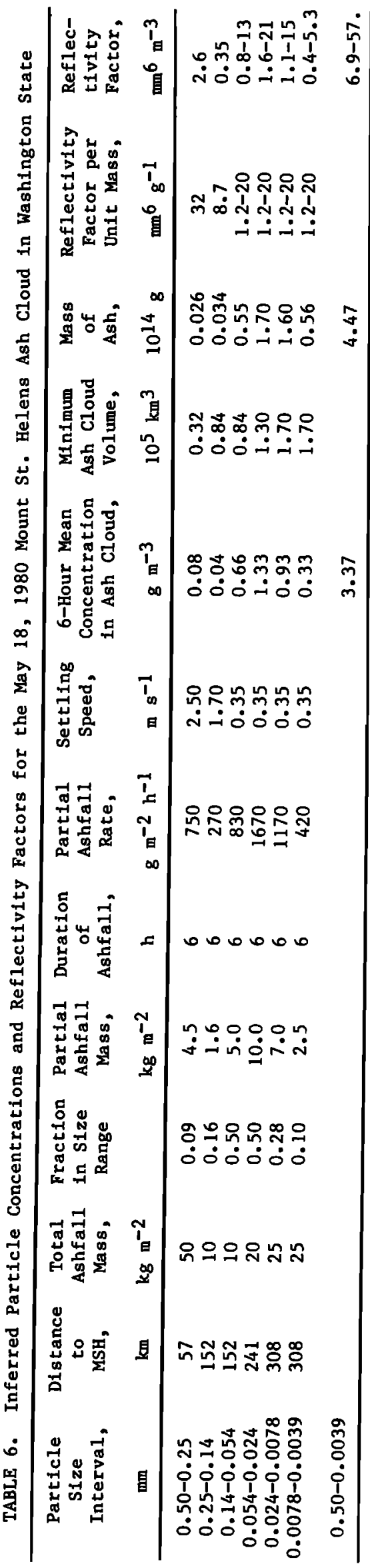


decreased due to fallout. The approximate volume of the ash cloud for which the concentrations of particles in each size interval is valid was estimated as the product of the following: (1) $70 \mathrm{~km}$, the mean width of the zone of high ashfall amounts from 60-300 km downwind from the volcano [Sarna-Wojcicki et a1., 1981, Figure 337]; (2) $12 \mathrm{~km}$, the estimated thickness of the eastward-moving ash layer and fallout zone [e.g., Harrts et a1., 1981; Danielsen, 1982]; (3) the approximate distance from the volcano where ashfall in the specified size range first becomes significant [Sarna-Wojcicki et a 1., 1981, Figure 342]; and (4) 0.66, the fraction of time during the 9-hour eruption that magma eruption rates and hence ash transport were significantly above the minimum values [Harris et al., 1981, Table 33]. The mass of ash erupted may be approximated as the sum-product of the respective ash cloud volumes and their 6-hour mean particle concentrations for the particle size intervals or about $5 \times 10^{14} \mathrm{~g}$ (see Table 6).

The reflectivity factors for the various sizes were calculated by assuming tephra clusters $0.2-0.5 \mathrm{~mm}$ in diameter [Sorem, 1982] with mean densities of $0.5 \mathrm{~g} \mathrm{~cm}^{-3}$ and, for particles larger than $0.14 \mathrm{~mm}$, by assuming properties similar to those for the March 19, 1982 ash cloud (Table 5). The estimated mean reflectivity factor for the whole ash cloud ranges from $7 \mathrm{~mm}^{6} \mathrm{~m}^{-3}$ to $60 \mathrm{~mm}^{6} \mathrm{~m}^{-3}$, depending upon the size distribution of tephra clusters. For portions of the cloud where ash coarser than 0.14 $\mathrm{mm}$ is absent, the reflectivity factor for residual finer ash would be at least $4 \mathrm{~mm}^{6} \mathrm{~m}^{-3}$ if the tephra clusters are at least $0.2 \mathrm{~mm}$ diameter. At the other extreme the reflectivity factor implied $\left(57 \mathrm{~mm}^{6} \mathrm{~m}^{-3}\right)$ for tephra clusters $0.5 \mathrm{~mm}$ diameter exceeds by a factor of 7 the value that was estimated from radar observations [Harris et a1., 1981]. The principal uncertainties are the sizes of the ash clusters and their effects on calculated radar reflectivities. Since the reflectivity factor inferred from radar data for this ash cloud was of the order $8.5 \mathrm{~mm}^{6} \mathrm{~m}^{-3}$ [Harris et al., 1981], we are confident that the true size of ash clusters is within the range $0.2-0.5 \mathrm{~mm}$. The settling velocities of tephra clusters are required for estimating the particle concentrations. The reflectivity factor and total ashfall mass depend, in part, upon the particle concentration inferred from ashfall data. Hence, because the calculated total ashfall mass ( $4.5 \times 10^{14} \mathrm{~g}$ ), which represents only ash that fell more than $60 \mathrm{~km}$ from the volcano, is consistent with comparable amounts reported by Sarna-Wojcicki et a1. [1981] and Carey and Sigurdsson [1982], and because use of higher settling velocities would give lower concentrations and diminished total ashfall mass, we conclude that the inferred ash cloud particle concentrations, the calculated radar reflectivity factors, and our methods for calculating these quantities are consistent.

\section{Discussion}

The duration of the Plinian phase during the May 18, 1980 eruption was about 9 hours [Harris et al., 1981], whereas ash emission lasted only
40-50 seconds for the March 19, 1982 eruption. The volumes of air fall ash for these eruptions differed by a factor of $10^{3}$. Radar observations of these very different scale eruptions and studies of the resulting ashfall help us to evaluate whether weather radar can be used to forecast volcanic ashfall. Physical data inferred for these two eruptions are summarized in Table 7.

The estimates of total ashfall mass based upon radar observations of the March 19, 1982 eruption are up to 3 times higher than estimates based on actual amounts over the study area. The result based on measured ashfall is poor 1 y constrained by itself. However, the total ashfall mass based upon the volume of the ash cloud determined by radar and the particle concentrations inferred from the ashfall data is probably the most accurate estimate, about $4 \times 10^{11} \mathrm{~g}$. This value is within the range inferred by radar and slightly higher than that estimated from the ashfall map. The particle concentrations inferred from radar observations are consistent with independent estimates based upon ashfall data, which are more precise. Ash cloud reflectivity factors calculated from ashfall data are consistent with calculated minimum values based upon detection of volcanic ash by radar from 1930-2030 PST and non-detection after 2030 PST, owing to diminished reflectivity factors resulting from ashfall. There is thus crude agreement among various results obtained independently from radar and ashfall data for the March 19, 1982 ash cloud.

Physical data Inferred for the May 18, 1980 Plinian eruption and ash cloud are summarized in Table 7. First, the total ashfall mass estimated by inversion of ashfali data (Table 6), which does not include ash that fell within $60 \mathrm{~km}$ of the volcano, is slightly lower than that of Sarna-Wojclcki et al. [1981] for their mapped area. A correction of $0.6 \times 10^{14} \mathrm{~g}$ for air fall ash within the proximal deposits (see Table 2 of Carey and Sigurdsson [1982] and Table 66 of Sarna-Wojc1cki et a1. [1981]) results in excel lent (probably fortuitous) agreement between the two estimates. Because of the large uncertainty in estimating the mass of far-flung ash that fell outside the area mapped by Sarna-Wojcicki et al. [1981], these estimates are lower bounds, according to Rose et al. [1983], whose higher estimate includes an upper limit for the mass of ash that fell outside the mapped area. The true ashfall mass is between about $4.8 \times 10^{14}$ and $6.5 \times 10^{14} \mathrm{~g}$ [Rose et al., 1983]. Our estimate for the total ashfall mass that is obtained by inversion of ashfall data after addition of the proximal ash (but still neglecting far-flung ash finer than about 4 micrometers) is about $5 \times 10^{14} \mathrm{~g}$, in close agreement with the minimum estimates of others. Minimum values inferred from radar calculations for the initial ash cloud [Harris et al., 1981] are larger but general1y consistent with other data in Table 7. The particle concentrations inferred from ashfall ( $\left.3 \mathrm{~g} \mathrm{~m}^{-3}\right)$ are minimum values because ash finer than 4 micrometers, much of which would have fallen outside the study area, was not included. Depending upon the relative abundance of finer ash and the mass of distal ash, other estimates (Table 7) suggest 
TABLE 7. Comparison of Ash Cloud Particle Concentrations, Total Ashfa11 Mass, and Radar Reflectivity Factors Inferred from Radar and Ashfall Observations

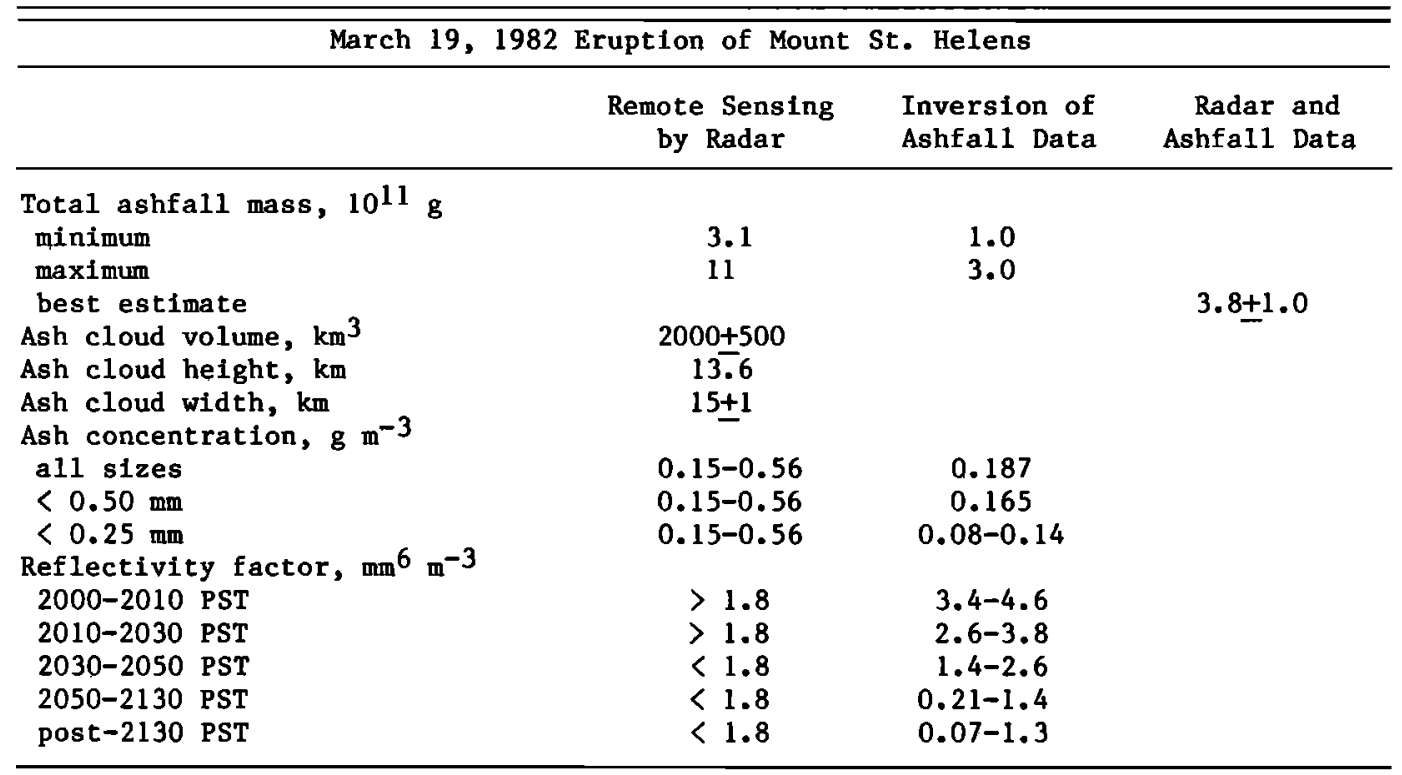

May 18, 1980 Eruption of Mount St. Helens

\begin{tabular}{|c|c|c|c|}
\hline & $\begin{array}{c}\text { Remote Sensing } \\
\text { by Radar }\end{array}$ & $\begin{array}{l}\text { Inversion of } \\
\text { Ashfall Data }\end{array}$ & $\begin{array}{c}\text { Other } \\
\text { Estimates }\end{array}$ \\
\hline $\begin{array}{l}\text { Total ashfall mass, } 10^{11} \mathrm{~g} \\
\text { minimum } \\
\text { maximum } \\
\text { Ash cloud volume } \\
\text { Maximum height, } \mathrm{km} \\
\text { Ash cloud width, } \mathrm{km} \\
\text { Ash concentration, } \mathrm{g} \mathrm{m}^{-3} \\
\text { 6-hour mean } \\
\text { a11 sizes } \\
<0.50 \mathrm{~mm} \\
<0.25 \mathrm{~mm} \\
\text { < } 0.14 \mathrm{~mm} \\
\text { Mean reflectivity factor, } \mathrm{mm}^{6} \mathrm{~m}^{-3}\end{array}$ & 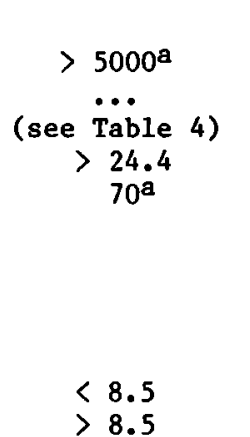 & $\begin{array}{l}>3.37 \\
>3.37 \\
>3.29 \\
>3.25 \\
6.9-57\end{array}$ & $\begin{array}{r}4900-5500^{\mathrm{c}} \\
4800-6500^{\mathrm{d}} \\
20^{\mathrm{e}} ; 25-28^{\mathrm{f}}\end{array}$ \\
\hline
\end{tabular}

\footnotetext{
atharris et a1. [1981]

b This value does not include airfall ash that fell less than $60 \mathrm{~km}$ from the volcano, about $600 \times 10^{11} \mathrm{~g}$, according to Table 2 of Carey and Sigurdsson [1982].

cSarna-Wojcicki et al. [1981, Table 66]

dRose et al. [1983]

epanielsen [1982], based upon effective radiation temperature at top of ash cloud

$f_{C .}$ Rice (data given by Sarna-Wojcicki et al. [1981, Figure 333], from triangulation measurements using satelite platforms)

gThis paper, based upon scaling the Rose et al. [1983] and Sarna-Wojcicki et al. [1981] estimates of total ashfall mass to that estimated in this paper by inversion of ashfall data and multiplying by $3.37 \mathrm{~g} \mathrm{~m}^{-3}$, which is the particle concentration inferred using ashfall data summarized in Table 6
}

that the 6-hour mean concentrations might have been as high as $5 \mathrm{~g} \mathrm{~m}^{-3}$. The higher concentration $\left(8.5 \mathrm{~g} \mathrm{~m}^{-3}\right)$, which was inferred from radar observations of the initial ash cloud [Harris et al., 1981], was based upon calculations that neglected the effects of particle aggregation on enhancement of the reflectivity. Also, because the eruption column height, magma eruption rate, and maximum reflectivity of the ash cloud varied significantly during the eruption [Harris et al., 1981], the particle concentration in an ash cloud that formed during the peak magma eruption rate might have been greater than the 6-hour mean. Given the many uncertainties confronted in this study, we feel our results are encouraging.

\section{Implications for Air Safety}

Volcanic ash clouds pose a significant hazard to in-flight aircraft (Table 8). Their detection and avoidance would reduce risks of both damaged aircraft and loss of 1 ife resulting from activity at known volcanoes along air routes. 


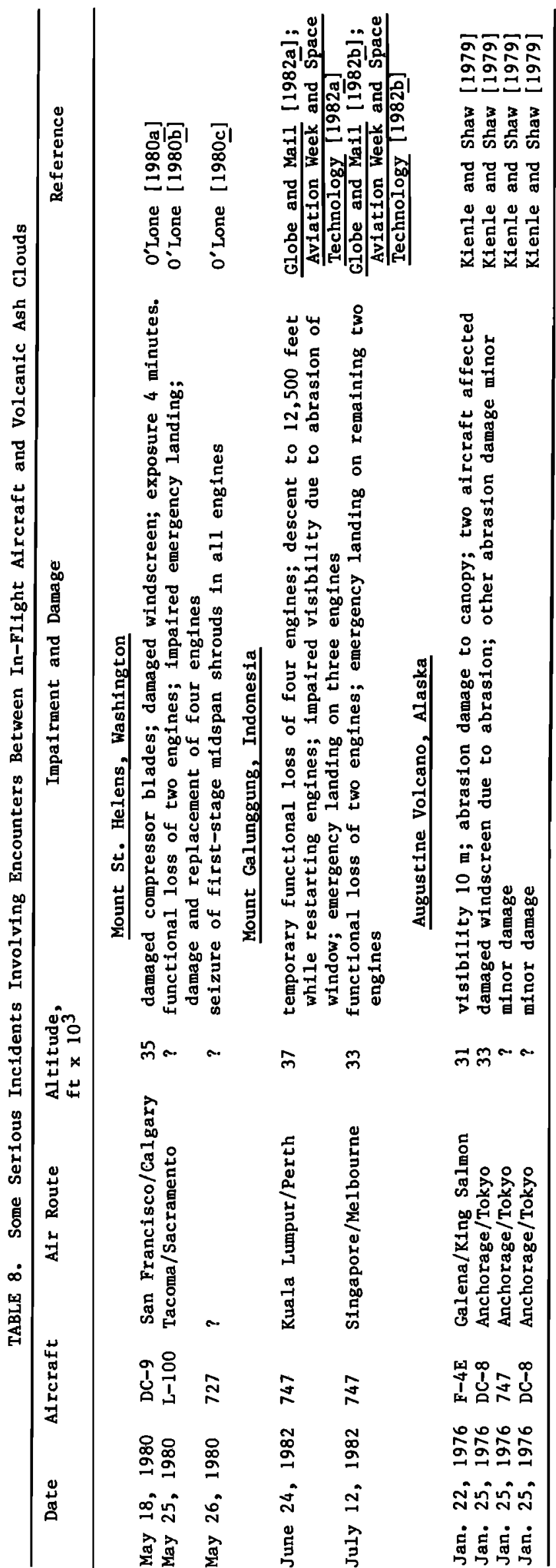

Unfortunately, visual detection requires that sufficient ash remain suspended at the cloud margins to impart a characteristic range of colors (light brown to black) to these clouds or that the cloud shape and extent uniquely identifies it as volcanic. Alternatively, meteorologfcal conditions which preclude the formation of the observed cloud might suggest the possibility of an eruption or ash cloud. However, such techniques are not useful during instrument flight at night or in overcast conditions. Indeed, the most serious incidents listed in Table 8 occurred at night and were apparently not detected on airborne weather radar. Typical radar reflectivity factors $Z$ for volcanic ash clouds of probable hazard to aircraft (cloud densities of $0.08-3.4 \mathrm{~g} \mathrm{~m}^{-3}$ ) may be estimated from data in Tables 5 and 6 to be in the range 0.2 to $7 \mathrm{~mm}^{6}$ $\mathrm{m}^{-3}$, respectively. Furthermore, the smaller refractive index factor, $|(\varepsilon-1) /(\varepsilon+2)|^{2}$, for the ash particles as compared to liquid water $(0.36$ versus 0.93) diminishes the detectability of an ash target by a factor of 2.6 relative to a rain target with identical particle size distribution and cloud density (see (1)). Therefore only a radar system that is capable of detecting rain with reflectivity factor equal to 0.077 to $2.7 \mathrm{~mm}^{6} \mathrm{~m}^{-3}$ would be able to detect typical volcanic ash clouds with densities of 0.08 to $3.4 \mathrm{~g} \mathrm{~m}^{-3}$, respectively. We emphasize that the reflectivity factors for typical ash clouds are several orders of magnitude smaller than those for severe weather (e.g., thunderstorms, hailstorms, tornadoes) considered detectable by airborne weather radar and dangerous for aviation [e.g., Treussart et al., 1970]. Also, volcanic ash clouds with particle concentrations of $0.2 \mathrm{~g} \mathrm{~m}^{-3}$ can be produced in extremely small eruptions (in terms of total ashfall mass) of duration less than 1 minute. Therefore we conclude that ash clouds resulting from explosive volcanic activity, regardless of eruption magnitude, must be considered an extremely serious hazard to in-flight aircraft.

\section{Conclusions}

Quantitative observations of volcanic ash clouds resulting from $P$ linian eruptions may be made using weather radar. Such observations allow estimation of eruption rates, durations of eruptions, representative grain sizes of pyroclasts in ash clouds, and the dimensions and trajectories of ash clouds. We have refined our use of these measurements sufficiently and tested our deductions by comparison with results obtained independently through inversion of ashfall data to allow forecasting of the locations, times, and amounts of ash fallout and to evaluate conditions of significant hazard to aircraft in the airspace traversed by ash clouds.

\section{Appendix}

The minimum value of the reflectivity factor $z=\left[(2 r)^{6}\right.$ required for detection of the March 19, 1982 ash cloud was determined from the radar equation (1), the antenna gain equation (2), the range $(R=74 \mathrm{~km})$ to the center of the ash cloud, and the parameters for the Portland NWS radar 
system (Table 1). We assumed that the power received from the radar detected ash cloud was equal to the detection 1 imit $\left(5 \times 10^{-14} \mathrm{w}\right)$ of the radar system. The dielectric constant of the solid (vesicle-free) silicate particles at a wavelength of $5 \mathrm{~cm}$ was assumed to equal that of Newberry obsidian at a wavelength of $8.6 \mathrm{~cm}$ (5.5, according to Campbe11 and U1richs [1969]). The minimum value of the reflectivity factor $Z$ for a target at range $\mathrm{R}$ kilometers required for detection by the Portland NWS radar is given by $\mathrm{Z}\left(\mathrm{mm}^{6} \mathrm{~m}^{-3}\right)=\left[(2 \mathrm{r})^{6}=3.3 \times 10^{-4}(\mathrm{R}, \mathrm{km})^{2}\right.$. For a range of $75 \mathrm{~km}, Z$ must be larger than about $1.8 \mathrm{~mm}^{6} \mathrm{~m}^{-3}$ for detection.

The reflectivity factors $Z$ per unit mass of ash for particles with diameters of $0.25 \mathrm{~mm}$ and $0.18 \mathrm{~mm}$ are $12 \mathrm{~mm}^{6} \mathrm{~g}^{-1}$ and $4.4 \mathrm{~mm}^{6} \mathrm{~g}^{-1}$, respectively. The minimum particle concentrations in the ash cloud can be estimated by dividing the inferred minimum reflectivity factor of the ash cloud by the reflectivity factor per unit mass of ash, weighted according to the mass fraction of particles in each size class (see Harris et a1., [1981] for details). Unfortunately, it is not possible to know a priori the particle size distribution in the ash cloud or to obtain it from conventiona 1 (non-Doppler) weather radar observations. However, a lower bound for the concentration of ash for all particle sizes can be calculated by assuming that all particles were $0.25 \mathrm{~mm}$ in diameter and the result is $0.15 \mathrm{~g} \mathrm{~m}^{-3}$. This value is also an upper bound for the concentration of ash coarser than $0.25 \mathrm{~mm}$ nominal diameter in the upper part of the radar-detected ash cloud (10.7 $\mathrm{km} \mathrm{as1)} \mathrm{at}$ 1950 PST (20 minutes after eruption) because any coarser ash intially present would have had settling speeds greater than $300 \mathrm{~cm} / \mathrm{s}$ and should therefore be absent at this and all higher elevations. Simllarly, an upper bound for the concentration of ash with nominal diameters between $0.18 \mathrm{~mm}$ and $0.25 \mathrm{~mm}$ in the upper part of the radar detected ash cloud at 1933 PST is obtained by considering the minimum concentration of $0.18 \mathrm{~mm}$ diameter particle required for detection in the target space above $10.7 \mathrm{~km}$ asl at 1950 PST (none was detected), which target space would contain on $1 y$ particles smaller than $0.25 \mathrm{~mm}$ diameter. This value is $0.41 \mathrm{~g} \mathrm{~m}^{-3}$. Furthermore, since (1) $0.15 \mathrm{~g} \mathrm{~m}^{-3}$ is an upper bound for ash coarser than $0.25 \mathrm{~mm}$ nominal diameter within the ash cloud at 1950 PST and at $10.7 \mathrm{~km}$ as 1 , and (2) $0.41 \mathrm{~g} \mathrm{~m}^{-3}$ is an upper bound for ash with nominal diameters between 0.18 and $0.25 \mathrm{~mm}$ within the ash cloud at 1950 PST and above $10.7 \mathrm{~km}$ as 1, it follows that the sum $0.56 \mathrm{~g} \mathrm{~m}^{-3}$ is an upper bound for the concentration of a11 particles with nominal diameters larger than $0.18 \mathrm{~mm}$. The concentration of ash finer than $0.18 \mathrm{~mm}$ cannot be determined from the present radar observations. In summary, the estimated lower and upper bounds on the concentration of ash coarser than $0.18 \mathrm{~mm}$ diameter are 0.15 and $0.56 \mathrm{~g} \mathrm{~m}^{-3}$, respectively. The true concentration must lie between the greatest lower bound and the least upper bound, which lie within this range.

Acknowledgements. We are grateful for the continuing interest of the National Weather Service (Portland, Oregon) in the application of weather radar to eruption clouds and appreciate the opportunity to study their detailed observations. D. M. Harris' research in the laboratory of Prof. C. M. Scarfe was made possible through receipt of an Izaak Walton Killam Memorial Fel lowship and a research grant from the University of Alberta. Participation in the American Geophysical Union Chapman Conference on Rainfa11 Rates, held April 27-29, 1982 in Urbana, Illinois, provided an opportunity for discussion of these results. Partial financial support for this work came from National Science Foundation grant EAR-82-05606 to W. I. Rose, Jr. We appreciate the helpful comments of the reviewers.

\section{References}

At las, D., Advances in radar meteorology, Adv. Geophys., 10, 317-429, 1964. Aviation Week and Space Technology, 117 (1), 27, 1982a.

Aviation Week and Space Technology, 117 (3), 29, $1982 \mathrm{~b}$

Campbeī1, M. J., and J. Ulrichs, Electrical properties of rocks and their significance for lunar radar observations, J. Geophys. Res., 74, 5867-5881, 1969.

Carey, S. N., and H. Sigurdsson, Transport and deposition of distal tephra from the May 18, 1980 eruption of Mount St. Helens, J. Geophys. Res., 87,7061-7072, 1982.

Critchfield, H. J., Problems in the cllmatology of the 1980 Mount St. Helens eruptions, in Atmospheric Effects and Potential Climatic Impact of the 1980 Eruptions of Mount St. Helens, edited by A. Deepak, NASA Conf. Pub1. 2240, pp. 203-209, Washington, D. C., 1982.

Danielsen, E. F., Mount St. Helens plume dispersion based on trajectory analyses, in Atmospheric Effects and Potential Climatic Impact of the 1980 Eruptions of Mount St. Helens, edited by A. Deepak, NASA Conf. Publ. 2240, pp. 141-153, Washington, D. C., 1982.

Danielsen, E. F., Geller, M. A., Laver, J. D., and $K$. R. Peterson, Transport and dispersion, in Report of Workshop on Mount St. Helens Eruptions: Its Atmospheric Effects and Potential Climatic Impact, edited by $R$. E. Newe 11 and A. Deepak, NASA SP-458, pp. 37-46, Washington, D. C., 1982.

Globe and Mail, Volcanic ash stops engines on jet, 41356, 13, 1982a.

Globe and Mail, Ash cloud forces jet to land, $41372,3,1982 b$.

Harris, D. M., Rose, W. I. Jr., Roe, R., and M. R. Thompson, Radar observations of ash eruptions, in The 1980 Eruptions of Mount St. Helens, Washington, edited by P. W. Lipman and D. R. Mullineaux, U. S. Geo1. Surv. Prof. Pap. 1250, pp. 323-333, 1981.

Hobbs, P. V., Radke, L. F., and J. L. Stith, Eruptions of the St. Augustine volcano: airborne measurements and observations, Science, 195, 871-873, 1977.

Kien1e, J. and G. E. Shaw, Plume dynamics, thermal energy and long-distance transport of vulcanian eruption clouds from Augustine volcano, Alaska, J. Volcanol. Geotherm. Res., 6 , 139-164, 1979 . 
Lipman, P. W., and D. R. Mullineaux, (Eds.), The 1980 Eruptions of Mount St. Helens,

Washington, U. S. Geol. Surv. Prof. Pap. 1250, 844 pp., 1981 .

Murrow, P. J., Rose, W. I., Jr., and S. Self, Determination of the total grain size distribution in a vulcanian eruption column and its implications to stratospheric aerosol perturbation, Geophys. Res. Lett., 7, 893-896, 1980.

o'Lone, $R_{0}$ G., Volcanic eruption disrupts air traffic, Aviat. Week Space Technol., 112 (21), $18-21,1980 a$.

o'Lone, $R_{0}$ G., Volcano continues to snarl air traffic, Aviat. Week Space Techno1., 112 (22), $18-19,1980 \mathrm{~b}$.

0 'Lone, Ro Go, Uncertainty over volcano continuing, Aviat. Week Space Techno1., 112 (25), $31-32$, 1980c.

Probert-Jones, J. Ro, The radar equation in meteorology, Q. J. R. Meteorol. Soc., 88, 488-495, 1962.

Rose, W. I., Jr., and M. F. Hoffman, The May 18 , 1980 eruption of Mount St. Helens: the nature of the eruption, with an atmospheric perspective, in Atmospheric Effects and Potential Climatic Impact of the 1980 Eruptions of Mount St. Helens, edited by A. Deepak, NASA Conf. Pub1. 2240, pp. 141-153, Washington, D. C., 1982.

Rose, W. I., Jr., Chuan, R. L., Cadle, R. D., and D. C. Woods, Small particles in volcanic eruption clouds, Am. J. Sci., 280, 671-696, 1980.

Rose, W. I., Jr., Harris, D. M., Heiken, G., Sarna-Wojcicki, A. M., and S. Self, Volcanological description of the 18 May 1980 eruption of Mount St. Helens, in Report of Workshop on Mount St. Helens Eruptions: Its Atmospheric Effects and Potential Climatic Impact, edited by R. E. Newe 11 and A. Deepak, NASA SP-458, pp. 1-36, Washington, D. C., 1982 .

Rose, W. I., Wunderman, R. L., Hof fman, M. F., and L. Gale, Atmospheric hazards of volcanic activity from a volcanologist's point of view:
Fuego and Mount St. Helens, J. Volcanol. Geotherm. Res., 17, 133-157, 1983.

Sarna-Wojcicki, $A_{0}$ M., Shipley, S., Waitt, R. B., Jr., Dzurisin, D., and S. H. Wood, Areal distribution, thickness, mass, volume, and grain size of air-fall ash from the six major eruptions of 1980, in The 1980 Eruptions of Mount St. Helens, Washington, edited by P. W. Lipman and D. R. Mullineaux, U. S. Geol. Surv. Prof. Pap. 1250, pp. 577-600, 1981.

Sorem, $R_{0} K_{0}$, Volcanic ash clusters: tephra rafts and scavengers, J. Volcanol. Geotherm. Res., 13, 63-71, 1982.

Swanson, D. A, Endogenous growth of the Mount St. Helens dacite dome (abstract), Eos Trans. AGU, 63, $1140,1982$.

Treussart, H., Beckwith, W. B., Bigler, S. G., Otani, K., Kostarev, V. V., and R. Schwarz, Use of Weather Radar for Aviation, WMO Tech. Note 110, 72 pp., Geneva, 1970.

Waltt, R. B., Jr., and D. Dzurisin, Proxima 1 air-fall deposits from the May 18 eruption stratigraphy and field sedimentology, in The 1980 Eruptions of Mount St. Helens, Washington, edited by P. W. Lipman and D. R. Mullineaux, U. S. Geol. Surv. Prof. Pap. 1250, pp. 601-616, 1981 .

Walker, G. P. L., Explosive volcanic eruptions - a new classification scheme, Geol. Rundsch., 62, 431-446, 1973.

Wilson, Ln, Explosive volcanic eruptions - II the atmospheric trajectories of pyroclasts, Geophys. J. R. Astron. Soc., 30, 381-392, 1972.

D. M. Harris, IRT Corporation, 6800 Poplar Place, McLean, VA 22101.

W. I. Rose, Jr., Department of Geology and Geological Engineering, Michigan Technological University, Houghton, MI 49930.

(Received April 11, 1983;

revised August 11, 1983;

accepted August 19, 1983.) 